\title{
Tourism Human Resources Develoment in Phu Quoc, Vietnam
}

\author{
Phan Quan Viet Ph.D. \\ Van Lang University, Vietnam
}

Received: September 12, 2018 Accepted: September 28, 2018 Published: November 12, 2018

doi:10.5296/ber.v8i4.13887

URL: https://doi.org/10.5296/ber.v8i4.13887

\begin{abstract}
The research was conducted to develop solutions for tourism human resource development in Phu Quoc. The study analyzes the needs of human resource development in tourism in Vietnam and highlights the experiences of human resource development in tourism in some provinces and cities in Vietnam and other countries in the world. From there, the study proposed four solutions to develop human resources for tourism in Phu Quoc including: using human resources, training human resources, attracting talents and experience in state management.
\end{abstract}

Keywords: Tourism human resources, Phu Quoc

\section{Introduction}

With the development policy of tourism economy to become one of the key economic sectors of the province in the upcoming time, leaders in all levels of Phu Quoc Suburban District have determined that the construction and development of tourism human resources is a key to bring Province's tourism to become one of the localities with a leading tourism development in the country based on the competitive advantages of tourism natural resources in the province. However, during the development of tourism industry in Phu Quoc Suburban District, the staff of the tourism industry has not exploited the advantages of tourism resources for the development of tourism yet. Therefore, it is necessary to build and perfect the team of staff in the tourism industry in the province in order to effectively exploit the tourism resource value with the desire to make Phu Quoc becomes a leading tourist center in the country and has a same level with the tourism centers of countries in the region and the world. The research project was carried out with the desire to propose solutions to develop tourism human resources in Phu Quoc in order to contribute to the development of Phu Quoc tourism industry. 


\section{Overview of the Need for Human Resource Development in Tourism}

At present, there are over 1.3 million laborers in tourism and relevant labors in the country, accounting for $2.5 \%$ of total labor force in the country, in which about 420,000 people work directly in service establishments. The sector's labor structure is occupied with $42 \%$ trained in tourism, 38\% trained from other sectors and about $20 \%$ without regular training, only on the job training. The distribution of laborers between fields and regions is not appropriate. The professional and skilled labors are both lacking and weak; the labors have not yet met the requirement are redundant; especially there is a lack of the trained laborers in new tourism regions.

Table 1. Forecast of direct human resource demand in tourism by 2020

\begin{tabular}{|c|c|c|c|c|c|c|}
\hline No. & Target & In 2012 & In 2017 & $\begin{array}{l}\text { The average } \\
\text { percentage of increase } \\
\text { in the whole period }\end{array}$ & $\begin{array}{c}\text { In } \\
2020\end{array}$ & $\begin{array}{c}\text { The average } \\
\text { percentage of increase } \\
\text { in the whole period }\end{array}$ \\
\hline & Total & 418,250 & 620,100 & 9.6 & 870,300 & 8.1 \\
\hline 1 & By sector & & & & & \\
\hline 1.1 & Hotels, restaurants & 207,600 & 312,100 & 10.1 & 440,300 & 8.2 \\
\hline 1.2 & $\begin{array}{l}\text { Travel, } \\
\text { transportation }\end{array}$ & 65,800 & 92,700 & 8.2 & 128,000 & 7.6 \\
\hline 1.3 & Other services & 146,200 & 215,300 & 9.4 & 302,000 & 8.1 \\
\hline 2 & By training level & & & & & \\
\hline 2.1 & Postgraduate & 1,450 & 2,400 & 13.1 & 3,500 & 9.2 \\
\hline 2.2 & Universities, college & 53,800 & 82,400 & 10.6 & 113,500 & 7.5 \\
\hline 2.3 & $\begin{array}{l}\text { Intermediate and } \\
\text { equivalent }\end{array}$ & 78,200 & 115,300 & 9.5 & 174,000 & 10.2 \\
\hline 2.4 & Elementary & 98,700 & 151,800 & 10.7 & 231,000 & 10.4 \\
\hline 2.5 & $\begin{array}{l}\text { Under elementary } \\
\text { (on-the-job training) }\end{array}$ & 187,450 & 268,200 & 8.6 & 348,300 & 5.9 \\
\hline 3 & By type of labor & & & & & \\
\hline 3.1 & Managing laborers & 32,500 & 56,100 & 14.5 & 83,300 & 9.7 \\
\hline 3.2 & $\begin{array}{l}\text { Professional } \\
\text { laborers }\end{array}$ & 387,100 & 564,000 & 9.2 & 787,000 & 7.9 \\
\hline & 1) Reception & 37,200 & 51,000 & 7.4 & 69,500 & 7.2 \\
\hline & 2) Chamber service & 48,800 & 71,500 & 9.3 & 98,000 & 7.4 \\
\hline & 3) Table, bar service & 68,400 & 102,400 & 9.9 & 153,000 & 9.8 \\
\hline & 4) Food processing & 35,700 & 49,300 & 7.6 & 73,400 & 9.7 \\
\hline & 5) Guidance & 20,600 & 30,800 & 9.9 & 45,000 & 9.2 \\
\hline & $\begin{array}{l}\text { 6) Travel office, } \\
\text { travel Agency }\end{array}$ & 31,100 & 52,600 & 13.8 & 81,400 & 10.9 \\
\hline & 7) Other staff & 145,300 & 206,400 & 8.4 & 266,700 & 6.0 \\
\hline
\end{tabular}

(Unit: Thousand people)

(Source: Institute for Tourism Development Research, 2018) 
According to Institute for Tourism Development Research, in 2018, tourism sector needs 620,000 direct laborers out of a total of 2.2 million jobs created by tourism and by 2020 will need 870,000 direct laborers out of a total of 3 million jobs created by tourism. The demand for human resources according to the structure of training level, field and occupation of each type of labor in each period is different depending on the demand for growth in each field.

According to the forecast above, the first half of the decade will need more human resources trained in the sectors with an annual increase rate of $9.6 \%$ and a slight increase of $8.1 \%$ in the next half decade. It can be seen that the scale of services continues expanding; the laborers of hotel, restaurant services will increase faster. The laborers need to be trained at the university level, the postgraduate level, managing laborers increase faster than the general level due to the demand of management; it needs more professional laborers in the coming time such as travel offices, travel agents, guidance by the expansion of many types of tourism; chamber, table, bar services also increases higher than the general level because this is the field needing more service laborers. Most types of labors increase slightly in the period 2017-2020. However, the demand for trained human resources still accounts for a large proportion, the ordinary labor force will decrease relatively and base mainly on seasonal laborers.

\section{Experience of Tourism Human Resource Development in Some Localities in Vietnam and in the World}

\subsection{Experience of Tourism Human Resource Development in Some Localities in Vietnam}

\subsubsection{Da Nang Province}

As of September 2017, the total number of visitors to Da Nang was 251,648, an increase of $3.06 \%$ compared to the same period in 2016. Among them, international visitors were 131,308 , an increase of $2.24 \%$ and domestic visitors were 110,200 , an increase of $1.15 \%$, outbound tourists were 10,140, accounted for $49.2 \%$ compared to 2016, travel revenue is 588 million dongs, an increase of $15.7 \%$ compared to 2016. With the characteristics of nature, population and the strong development of the tourism industry, the development of tourism human resources is one of the urgent requirements to make Da Nang tourism become one of the localities with the leading development of tourism industry in the country. To successfully implement this mission, the leaders of Department of Culture, Sports and Tourism in Da Nang have successfully implemented many solutions to develop tourism human resources for the province such as:

- To proceed with the classification of visitors to accurately determine the service needs of the human resource for those visitors, from then, there is a strategy to train accordingly.

- To build policies to attract talents for the purpose of attracting highly qualified human resources to work at province.

- To coordinate with tourist business establishments in the locality as well as domestic and foreign tourist business establishments in practical training for Da Nang tourism human resources.

- To build and develop a system of schools and centers for training of tourism human 
resources in the province to meet the development needs of the tourism industry.

\subsubsection{Khanh Hoa Province}

Khanh Hoa has a coastline of over $200 \mathrm{~km}$ and nearly 200 islands with many beautiful bays like Van Phong, Nha Trang (one of the 29 most beautiful bays in the world). With these advantages, Khanh Hoa has become one of the major tourist centers in Vietnam.

Since 2001, the province has trained over 900 managing staff and employees serving in this sector. In addition, the professional high schools, universities, colleges in the province implemented the program integrating, introducing Khanh Hoa's culture and tourism in the school's social science subjects, organized short-term and long-term training classes, major in tourism with nearly 3,000 trainees. Tourism business establishments, especially high-ranking ones rated at 3 stars or more, have actively organized on-the-job training programs or contracts with schools to organize training classes on demand of the unit. In 2016, the number of staff serving in the tourism industry of Khanh Hoa Province is 4,354. By the year 2017, there will be 8,900 people (in which trainees are trained in tourism in schools, institutes and centers of Khanh Hoa Province are 1,809 trainees).

\subsubsection{Quang Ninh Province}

In recent years, due to the concern of investment in infrastructure of the Government, tourism development policies, advertising, promotion, and improvement of service quality, tourism in Quang Ninh has a strong development. According to statistics, the average growth rate of tourists to Quang Ninh is $14.4 \%$ per year; the growth of tourism revenue is $37 \%$ per year. These results come from the correct policy of provincial departments. Quang Ninh Province has identified the tourism human resource as the most important factor to successfully implement the policy of developing tourism into a key economic sector, the motivation for the development of service and improvement of livelihoods. Thanks to that, the training of human resource has been highly invested by the province such as the tourism sector in the province has cooperated with major training establishments such as Faculty of Tourism, Hanoi University of Social Sciences and Humanities, University of Economics and Hanoi Tourism College, etc. to open classes close to the practical needs. Through this, I can be updated and refreshed professional knowledge, working attitude and ability of foreign language communication of the workforce. In addition, some high-ranking business establishments rated 4 stars or more and inviting foreign experts to provide on the job training for staffs of enterprises, improve their professional level in order to meet the standard requirements on the skills of direct labor in their businesses better.

\subsection{Experience of Tourism Human Resource Development in Some Countries in the World}

\subsubsection{Thailand}

Thailand's government has always considered developing human resources as one of the top priorities in the national development plan. The tourism development plan focuses on handling issues on vocational training, tourism arising from the mission requirements of the tourism industry in Thailand. 
Policy on the development of tourism human resources to serve the industrialization process in Thailand, implemented by the following main programs: Strengthening vocational education and professional tourism technique; emphasize practical skill training for tourism; encourage internal training (training in Tourism). In Thailand, tourism human resource development programs are performed with cooperation between the government and the private region. This cooperation reflects the link between education and vocational training, a link between system of schools and factories. There is a link between the government and the private sector, private schools in the field of tourism vocational training.

\subsubsection{Japan}

The human resource development system in Japan is called the lifelong development system. The development of human resource is conducted from easy to difficult, from simple to complex, from basic training to application, performs continuously and suitably for laborers. These activities ensure steady career advancement over time, concurrently empower laborers to adapt to changes in the labor market.

The process of human resource development in tourism is carried out in a system of three forms: public training, business training and self-training. Training in Japan is very important, for simple occupations such as chamber, laundry, restaurant services etc. training at the workplace is the main, and there is a mechanism to encourage self-study, self-learning, lifelong learning and life-long association with community enterprises. The role of the Government is most clearly expressed in public training, but not limited, but also expresses relationships between enterprises and laborers, as well as through building the legal and institutional frameworks and plans to support the capacity development process of the laborers.

Human resource development plan: The Ministry of Labor prepares a basic plan that will provide the basis for vocational training, skills testing and other career development in accordance with labor market requirements, assure to satisfy the requirements and aspirations of the laborers in a constantly changing environment.

The system of organization, management and development of human resource in Japan is organized nationwide at both national and local (province) levels. The Department of Human Resource Development under the Ministry of Labor of Japan is responsible for the entire management of the human resource development system and international cooperation.

Human resource development in the private sector: The development of human resource is carried out by large companies in a relatively independent manner. Companies often have training establishments and human resource development programs systematically.

The human resource development system in Japanese factories has the following basic characteristics:

- On-the-job training is the main form, including on-the-job formal training (usually for new entrants) and informal training, which is carried out throughout the employee's working life through mentoring and guidance of experienced and skilled craftsmen to those with lower 
skills;

- The content of informal on-the-job training is very broad and long-term and is implemented step by step and systematically. On-the-job training is widely applied in large companies and in a smaller scope to small and medium companies. The Government supports these activities in the form of human resource development allowance (from one third to a half of the cost of operation, one third to a half of tuition); allowances for striving persons, including tuition and salary allowance (one fourth of a monthly salary in large companies and one third of laborers in small and medium companies)

\subsubsection{Federal Republic of Germany}

Investment in education in the Federal Republic of Germany is very large, accounting for about $5-6 \%$ of national income, so the conditions of technical facilities and teachers for education and training system in the Federal Republic of Germany are very good compared with other countries. Contributions to investment in education are mainly from local government (state) budgets.

Often, trainees begin training after the $9^{\text {th }}$ or $10^{\text {th }}$ grade. The duration of vocational training is usually three years. At this age, up to $75 \%$ of people choose the vocational training path, in which three fourth is followed by the system of vocational training in the form of training at enterprises and schools (called Dual System), while the remaining one quarter is in pure vocational schools. The majority of the costs for vocational training in the dual system are covered by enterprises (87\%); this cost is more than 2.8 times the budget spent by the Government on vocational schools. For tourism training, this type of training exists through the professional college system (Hotelberufschule or Fachhochschule); practical and applied training.

\section{Experience Lessons for Tourism Human Resource Development in Phu Quoc}

From experience lessons in some above localities, the experience lessons for Phu Quoc are as follows:

- Experience from the use of tourism human resources: the use of tourism human resources in service business establishments should be derived from the passion of the individuals in the tourism industry, which creates stability in sector as well as the laborers can accumulate experience and qualifications to better serve for the tourism industry. It is essential to separate the tourists to arrange laborers with professional levels which suits for each tourist to improve service quality.

- Experience in training: It is necessary to build a professional and high quality training system. Training program must be close to reality as well as link training at training centers with enterprises in province and country. Training of tourism human resources must be based on the actual needs of the sector, training with a focus and the depth of the specific sector. Training should be closely linked to the development strategy of the tourism industry in the province, especially the training of high quality workforce with specialized knowledge and foreign language skills. 
- Experience in attracting talents: It is necessary to determine that attracting talents is one of the important strategies to improve the quality of tourism human resources, concurrently creating a competitive motivation for development among laborers in the sector and developing policies to attract talents in accordance with socio-economic development policies of the province.

- Experience lessons from state management: Strengthening the state management from the highest to the lowest level in the tourism sector. The State needs special support, concern to the development of vocational education. It is considered as a key to the success of tourism development. In order to develop tourism human resources to meet the requirement of strengthening human resource management in the development of tourism human resources through tools such as building and promulgating development policies, building strategies and plans for development in tourism and developing tourism human resource. The State should actively build the tourism training system together with the law system on education, vocational training law, labor law.

\section{Conclusion}

Da Nang, Khanh Hoa and Quang Ninh can be considered as the three leading tourism development centers of the country with the various forms of sea and mountain tourism etc. there is a similarity with the tourism forms in Phu Quoc. Therefore, learning experience from the tourist centers above as well as the experience of human resource development in countries in the world is essential for the development of human resources in general and tourism human resources in particular. Phu Quoc should take advantage of its available tourism advantages, combining with training policies, attracting talents, policy incentives to develop better tourism human resources for the locality.

\section{References}

Canh Chi Hoang \& Tran Vinh Hoang (2013). Training and Development of Human Resources in some countries and experience lessons for Vietnam.

Da Nag (2016). Province Department of Culture, Sports and Tourism. The Conference on tourism activities in 2016 and mission implementation in 2017.

Institute for Tourism Development Research (2017). Vietnam tourism development strategy to 2020 , vision to 2030 .

Khanh Hoa Province (2012). Department of Culture, Sports and Tourism. Tourism Action Program for 2012-2017 and orientation to 2020.

Le Thi My Linh (2009). Doctoral thesis, Human resource development in small and medium enterprises in Vietnam in the process of economic integration.

Nguyen Loc Ph.D. (2012). Basic and theoretical issues in Human Resource Development in Vietnam.

Nguyen Minh Ngoc (2009). Thailand's international tourism development experience and suggestions for Vietnam. 


\section{Macrothink}

Business and Economic Research

ISSN 2162-4860

2018, Vol. 8, No. 4

Nguyen Thi Anh Dao (2011). Development of high quality human resources - attraction from Da Nang.

Nguyen Van Diem \& Nguyen Ngoc Quan (2004). Human Resource Management curriculum, Social Labor Publisher.

Pham Minh Hac (1996). The human issues in the career of industrialization and modernization, National Political Publisher, Hanoi.

Pham Van Duc Ph.D. (2013). The role of human resources in the process of industrialization and modernization in Vietnam today.

Quang Ninh (2014). Province Department of Culture, Sports and Tourism. Tourism brand positioning.

Tran Kim Dung Ph.D. (2012). Human Resource Management, General Publisher, Hochiminh City.

Tran Son Hai (2011). Doctoral thesis, Human resource development in tourism in the South Central and Highlands.

Tran Xuan Cau \& Mai Quoc Chanh (2008). Human Resource Economics Curriculum, Publisher, National Economics University, Hanoi.

\section{Copyright Disclaimer}

Copyright for this article is retained by the author(s), with first publication rights granted to the journal.

This is an open-access article distributed under the terms and conditions of the Creative Commons Attribution license (http://creativecommons.org/licenses/by/3.0/). 